Volume 8

Issue 1 March

Article 17

March 1981

\title{
Benefits for the Disabled: How Beneficial for Women?
}

Elizabeth Ann Kutza

University of Chicago

Follow this and additional works at: https://scholarworks.wmich.edu/jssw

Part of the Gender and Sexuality Commons, Medicine and Health Commons, and the Social Work Commons

\section{Recommended Citation}

Kutza, Elizabeth Ann (1981) "Benefits for the Disabled: How Beneficial for Women?", The Journal of Sociology \& Social Welfare: Vol. 8 : Iss. 1 , Article 17.

Available at: https://scholarworks.wmich.edu/jssw/vol8/iss1/17

This Article is brought to you by the Western Michigan University School of Social Work. For more information, please contactwmu-scholarworks@wmich.edu.

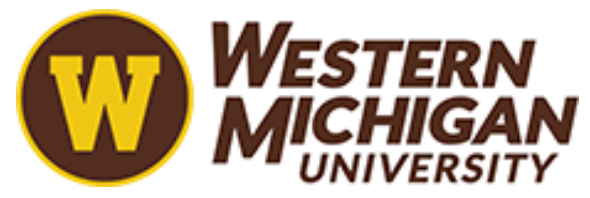


BENEFITS FOR THE DISABLED: HOW BENEFICIAL FOR WOMEN ?

Elizabeth Ann Kutza, Ph.D. The University of Chicago School of Social Service Administration

\begin{abstract}
The social and economic consequence of disability is of increasing interest in American society today. The numbers of persons reporting disabling conditions is rising, as is the number of persons qualifying for public disability benefits. This article examines the impact of current United States disability policy on disabled women, and concludes that the major programs -- disability insurance, supplemental security income, workers' compensation, vocational rehabilitation -because of their relationship to labor market participation, disadvantage women. Women not only receive fewer, but less generous benefits. Explanations of this outcome, and implications for future policy are addressed.
\end{abstract}

\title{
Introduction
}

The 1980s are likely to bring with them increased attention to the social and economic consequences of disability. Already this concern has been exhibited nationally through the convening of the 1977 White House Conference on Handicapped Individuals, and internationally through the designation of 1981 as the International Year of Disabled Persons. The highly symbollic political attention to the circumstances of disability in the American polity has emerged from three sources. One is the public's increased awareness of the extent of disability in our soclety, another is the increased cost associated with public and private disability benefits, and a third is the increased demands of the disabled themselves.

Not until the 1970 Census was there any systematic attempt to identify the number of disabled persons living in the United States. The Census counted 11.2 million persons between the ages of sixteen and sixty-four (one in eleven persons) with functional disabilities. of this number, approximately 1.7 million persons were homebound due to chronic health disorders or degenerative diseases, and 2.1 million 
were institutionalized (President's Cormittee on Employment of the Handicapped, 1977). In 1972, the Social Security Administration conducted its Survey of Disabled and Nondisabled Adults, and counted one in nine persons disabled ( 15.6 million persons between the ages of twenty and sixty-four) including approximately 7.7 million severely disabled (Allan, 1976).

Those first attempts at enumeration, however, have been criticized as underestimating the numbers of disabled persons in our country. The disability classification used in both surveys is based upon the individual's capacity to work. Those whose health prevents or limits them from working are classified as disabled. But many disabled persons do work, hence their disability is not an impediment to employment. Such persons, as well as persons over age sixty-four, are omitted from among the disabled by the Census and the Social Security Administration surveys.

Responding to the limitations of these studies by expanding the concept of disability, two alternate estimates of the number of disabled in our society have been put forth. The White House Conference on Handicapped Individuals estimated that 33 million persons living in the United States have physical or developmental disabilities, while the American Coalftion of Citfzens with Disabilities estimates the number at 36 million -- one in six persons. Thus the sheer number of persons having some handicapping condition has elerted policymakers and the public to the needs of this group.

While it is not known whether physical and developmental disabilities among adults are on the rise In American society (since most enumerating attempts have been so recent), it is apparent that the number of persons who qualify for public benefits on the basis of disability is increasing. The numbers of workers who qualified for social securtty disability insurance benefits, for example, has doubled in seven years. The cost of the program has quadrupled since 1970 (Singer, 1978). Under the supplemental security income program, too, benefit receipt contingent upon disability is the fastest growing component. Workers' compensation and state vocational rehabilitation programs also are experlencing rapid growth. (Between 1977 and 1978, workers' compensation benefit outlays increased from $\$ 3.9$ to $\$ 5.8$ bilition).

Many provisions of the programs themselves have contributed to these increases, Dut the experiences of privately financed disability plans, and of government programs in other countries generally have paralleled those of federal and state programs. Hence one conclusion 
might be that the public acceptance of the government's role in compensating for the functional limitations brought about by disability is growing. In 1979, federal benefit outlays for the disabled were estimated at totaling $\$ 35$ billion (U.S. Office of Management and Budget, 1979). These growing budgetary outlays naturally have brought public disability programs increased -- and often unwelcome -- attention from national policymakers. And this attention predictably will continue.

A final impetus to the public concern about disability has come from the disabled themselves. Increased militancy by advocates of the disabled has generated new programs, and placed new demands on policymakers. The disabled are striving to achieve mainstreaming in education, barrier free environments, special transportation facilities, and equal access rules. Exercising their political muscle, the disabled have witnessed mixed results. While new programs are being developed, the budgetary implications of these demands are generating alarm and resistance at all levels of government.

Three factors, than, are combining to propel social policies for the disabled into the forefront of our national agenda for the $80 \mathrm{~s}$. As existing programs undergo new scrutiny, it is appropriate to ask how their benefits affect disabled women. This paper will explore the impact on disabled women of current Untted States policy for disabled persons.

\section{Programs That Benefit the Disabled}

Programs aimed at assisting the disabled have a long historical tradition. The lame, as they were earlier called, were regarded along with the aged and children as unable to fully participate in the economic activity of society. Because this inability to contribute was involuntary and unchanging, such individuals were seen as deserving of support by the larger collectivity. Resources generated by the ablebodied were transferred to the lame individual as part of a social contract. In early societies this transfer of resources occurred informally through family or clan; in more developed industrialized societies this collective responsibility has shifted to the formal organizations of goverment through the implementation of public policies.

Currently there are a wide range of benefits available to disabled individuals through public programs. Most of these programs are administered and funded by the federal government. Officlal government estimates identify more than 120 programs and activities serving handicapped individuals sponsored by twenty federal departments (U.S. Depart- 
ment of Health, Education, and Welfare, 1978a). Several of these programs provide services to children or the aged, but the majority of public policies that concern themselves with disability are directed to working-age adults. And the major purpose of these programs is either to replace earnings lost through disability, or to provide services that rehabilitate handicapped persons so they may reenter the labor force and become self-sufficient. The four most significant programs are the disability insurance program under social security (DI), the supplemental security income program (SSI), the state workers' compensation, and vocational rehabilitation programs.

Disability Insurance Under Social Security

The social insurance features of United States social security policy, embodied in Title II of the Social Security Act, provide for the partial replacement of earnings lost to workers and their dependents because of the worker's retirement in old age (old age insurance), disability severe enough to prevent substantfal gainful employment (disability insurance), or death (survivors' insurance). Disability insurance pays wage-related benefits to the worker, the worker's children, and the caretaker (usually the mother) of the children of the disabled worker. In July 1979, the disability insurance cash benefit program provided monthly benefits to about 2.9 million disabled workers and 1.9 million dependents of disabled workers.

While now an integral part of the social security system, disability insurance provisions were enacted twenty-one years after the retirement program, and seventeen years after enactment of survivors' insurance. "The delay," In the words of the 1979 Advisory Council on Social Securfty, "was the result, in part, of fears that providing social security disability benefits would discourage rehabilitation and encourage malingering, and that the costs of disability insurance would be difficult to control." (U.S. Advisory Council on Social Security, 1979 , p. 139). These fears led to the adoption of a very limited disabllity insurance program in 1956. Only persons aged fifty and over were eliglble for beneftts. By 1960, benefit eligibility was liberalized, and coverage under DI began to parallel coverage under the old age and survtvors' insurance provisions.

Benefit entitlement and benefit eligibility continued to liberalize in the 1960s and 1970s, and by 1975, the number of workers being awarded disability benefits was roughly twice its 1965 level. After 1975, however, the number of new awards declined, although benefit outlays continued to rise. Recent leglslative proposals have been afmed at curtalling these continually rising costs. 
Eligibility for disability insurance benefits are contingent upon three things: (1) insured status; (2) disability status; and (3) age. A worker must by sixty-four years of age or younger, and have a required number of quarters of coverage to be fully insured under the program. For fully insured status, a worker must have twenty quarters of coverage in the forty quarters preceding the onset of his/her disability. (A quarter of coverage is a calendar quarter in which the individual receives wages of $\$ 50.00$ or more.) In effect, than, at the time of his/ her disability, an individual would have to have contributed to the social security system at least five of the preceding ten years.

In addition to fully insured status, an individual must fit the statutory definition of disability to be eligible for benefits. In the Social Security Act and its regulations, disability is defined as "the inability to engage in any substantial gainful activity by reason of any medically determinable physical or mental impairment which can be expected to last for a continuous period of not less than twelve months. A person must be not only unable to do his/her previous work or work commensurate with the previous work...but cannot, considering age, education, and work experience, engage in any other kind of substantial gainful work which exists in the national economy..." (U.S. Department of Health, Education, and Welfare, 1974). Under current regulations, earnings of more than $\$ 280.00$ a month for nine months are assumed to demonstrate an ability to engage in "substantial gainful activity" $(\mathrm{SGA})$, and thus result in a loss of benefit entitlement.

The disability insurance program is financed by part of a payroll tax paid half by the covered employee and half by the employer, and a tax paid by self-employed people on their earnings. Persons who have not contributed to the social security system are not eligible for benefits. The disability insurance program is administered by the Social Security Administration.

\section{The Supplemental Security Income Program}

The Social Security Administration administers a second program that pays benefits to the disabled. Also part of the Social Security Act (Title XVI), the supplemental security income program (SSI) provides benefits to the nonaged blind and disabled in financial need, as well as to people aged sixty-five and over who are in financial need. While disability insurance provisions are a fairly recent addition to the Social Security Act, aid to the needy blind dates back to the original Act of 1935. Under the 1950 social security amendments, federal matching funds were also provided to states that wished to provide public assistance payments to persons who were "permanently 
and totally" disabled. In 1974, SSI, a federally administered and financed program of assistance using a federal definition of disability and a unfform federal payment standard, replaced these various federal/ state programs.

SSI, unlike DI, is not a social insurance program but a welfare program. Benefits are based upon one's current income status, unrelated to past contributions or work history. The program provides a federal minimum level of income to those disabled who meet income and resource tests. As of July 1980, SSI benefits of $\$ 238$. no per month for an individual and $\$ 357.00$ for a couple were the maximum amounts payable to those with virtually no other income. As income from other sources increases (excepting certain disregards), SSI payments are reduced. About 1.9 million blind or disabled persons under age sixty-five were receiving benefits under the supplemental security income program in mid-1979.

\section{Workers' Compensation}

Workers' compensation is a system of state-sanctioned insurance programs that are to provide protection against loss of income, medical expenditures, or death due to injurles on the job. While the first workers' compensation program was enacted in the early 1900s, It was not unt11 1949 that all states had adopted workers' compensation programs. By 1978, nearly 90 percent of the labor force was covered by programs which would compensate for work-related accidents or occupational diseases.

Since 1 t is a state program, workers' compensation lacks uniformity among jurisdictions in coverage, benefit structure, and administration. Unlike DI and SST, which by definition include only the most severely disabled, workers' compensation is designed to cover the entire range of disabilities, of which only a small percentage are long-term and severe. As a consequence, workers' compensation has developed a far more flextble eligibility/benefit structure that can differentiate between permanent and temporary, as well as total and partial disability (Joe and Bogatay, 1980).

Workers' compensation is intended to protect employees from health hazards at their place of work. As a consequence, benefits are closely tied to the work-relatedness of the disability. In general, to qualify for benefits, the employee must have sustained an injury or been killed in performing his duties, but the injuries or death must not have arisen due to the employee's gross negligence, willful misconduct, or intoxication. Workers' compensation programs are financed almost entirely 
by employers. In 1978 , the total paid under the various state and federal workers' compensation plans was about $\$ 8.7$ billion.

\section{Docational Rehabilitation Services}

The three programs just reviewed provide cash benefits to disabled workers. Their purpose is to partially replace income lost because of a disability. There exist another set of programs which provide services to the disabled, services intended to rehabilitate. The largest of these is the vocational rehabilitation (VR) program.

All beneficiaries of the DI and SSI programs are categorically eligible for consideration for state vocational rehabilitation services. By statute, all beneficlarles who have the potential to engage in substantial gainful activity must be referred for consideration. To serve these clients the states administer three vocational rehabilitation programs: a basic state program, and two special programs mandated by the Social Security Act - one for DI beneficiaries (paid out of the Social Security Trust Fund), and the other for SSI beneficiaries (paid out of general revenues). The federal goverment funds 100 percent of the special programs and 80 percent of the basic program.

Services of all forms can be provided to the disabled under VR programs - medical, psychological, training, tools, and placement. These services are to be provided to any severely disabled individual, without regard to financial need, under two conditions: there is a physical or mental disability that results in a substantial impediment to employment, and there is a reasonable expectation that vocational rehabilitation services may benefit that individual in terms of employment. The purpose is to rehabilitate individuals towards "maximum participation in gainful employment." (Joe and Bogatay, 1980, p. 46).

In 1977, expenditures for all three programs exceeded $\$ 1$ billion, and about 1.9 million persons received services. of these, close to 300,000 were claimed "rehabilitated," at a cost of about $\$ 3,000$ per rehabilitation (U.S. Department of Health, Education, and Welfare, 1978b).

\section{Commonality of Programs}

The common element underlying each of the programs described above is their relationship to work in soclety. These programs only offer benefits to a disabled person who cannot work in the marketplace. They either try to make that person "more employable," or give him or her a stipend. Even rehabilitation services, with their emphasis on "vocational rehabilitation," have been seen from their inception in 1920 as 
a way of saving money and increasing industrial output, rather than as a method of reintegrating disabled people into society (Erlanger et al, 1979). Both disability insurance and workers' compensation benefits are contingent upon labor market participation, while the supplemental security income program incorporates in its disability definition the criterion of the capacity to engage in substantial gainful activity. Because women have historically had weaker ties to the labor market, this benefit contingency on labor market participation has meant that these programs have been less responsive to the needs of disabled women.

\section{Women and Disability}

The Social Security Administration's (SSA) 1972 Survey of Disabled and Nondisabled Adults provides the best available data on the prevalence and nature of disability among adult Anerican women. It also provides data on womens' participation rates in the disability insurance and supplemental security income programs. Two findings emerge:

- women represent a somewhat greater proportion of persons in the population who report suffering from one or more chronic conand yet, ditions or impairments,

- women are less likely than men to recelve public income maintenance benefits (Allan, 1976; Posner, 1977; Krute and Burdette, 1978).

The implicattons of these two findings for the econonic well-being of the disabled woman in the United States are very serious.

\section{Sex Differences in the Prevalence of Disability}

In the 1972 SSA Survey, disability prevalence was found to be greater among women than among men ( 15.2 percent of women had some impairment compared to 14.0 percent of men). Not only were women more likely to report a chronic disease or impairment, but the condition was more likely to result in a severe disabllity. Eight percent of the women but only 6 percent of the men reported that they were severely disabled. Table $I$ displays these different prevalence rates by sex.

The 1976 Survey of Income and Education conducted by the Bureau of the Census reports similar findings. Of the 28.2 million people three years old and older who were reported to have some activity limitation due to a health condition, about 53 percent were women (U.S. Department of Health, Education, and Welfare, 1979a). 
TABLE 1

Disability Prevalence Rate (per 1,000 population), By Sex

\begin{tabular}{l|c|c}
\hline Population & Men & Women \\
\hline With chronic conditions & 464.7 & 507.3 \\
Disabled & 139.6 & 152.4 \\
Severely disabled & 59.0 & 85.0 \\
\hline
\end{tabular}

Source: Aaron Krute and Mary Ellen Burdette, "1972 Survey of Disabled and Nondisabled Adults: Chronic Disease, Injury, and Work Disability." Social Security Bulletin, 41:4 (1978), p. 10 .

When these differences are looked at by major disease group, women report higher rates of cardiovascular diseases (primarily peripheral vascular disorders such as varicose veins and high blood pressure), mental disorders, urogenital conditions, neoplasms, and endocrine disorders. According to the Social Security Administration, the excess of urogenital and endocrine disease among women is due to disorders of the female reproductive system and to thyroid problems, respectively. More women than men also report visual problems -- serious difficulty seeing or blindness.

While accidents and injuries caused a significant proportion of the chronic diseases and/or impairments reported by SSA survey respondants in general, on this dimension women are underrepresented. The proportion of men with an accident-related condition ranged from 16 percent of the nondisabled to 31 percent of the currently disabled. The comparable figures for women were 5 percent and 18 percent, respectively (Krute and Burdette, 1978).

Looking at other demographic variables, the composition of the disabled is heavily weighted toward older people. Most chronic conditions and impairments take years to develop. For any condition, the rates for persons aged fifty-five to sixty-four are from one and one-half to three times htgher than for persons under forty-five. Not only are older persons more likely to suffer from a chronic condition or impairment, but also they are much more likely to be disabled as a result. But as Allan points out, "Some of the relationships between age and disability may...reflect the work-related definition of disability. Regardless of health, many people begin to work less in their late fifties and early sixties as a mode of preparation for retirement.... 
The availability of social security benefits reinforces the effects of $i 11$ health on encouraging retirement." (Allan, 1976).

As with age and sex, the composition of the disabled population is heavily weighted toward those with low educational attainment. More than 40 percent of the severely disabled group had no high school. And related, blacks and other nonwhites are more heavily represented among the disabled than among the general population.

Finally, the disabled population -- in particular, the severely disabled - - is composed of unmarried individuals to a larger extent than the nondisabled population. Since the disabled are older than nondisabled, they are more likely to be widowed, separated, or divorced.

Work Limitation and Disability Among Women

Women not only report themselves as more disabled when asked, they also report more serious work limitations as a result of their disabi1ity. In 1976, the Bureau of the Census found 13.3 percent of the 124.6 mflition Americans between the ages of eighteen and sixty-four reporting some level of work disability. But a breakdown by sex, marital status, and household relationships as they reflect level of work disability shows some significant differences. (See Table 2)

The implications for women of the data in Table 2 as regards their receipt of benefits under current United States programs for the disabled are important. First, the data make clear that women suffer more serious work disability than men. Their disability is more likely to prevent them from working at all, or from working regularly. The disparity between men and women on these measures is observable from age thirty onward, and steadily increases with age.

Women who suffer a work disability are also more likely than men to be living without a spouse. This sex-related difference is greatest among those women whose disability is severe enough to prevent them from working. Additionally, the extent of disability found among persons who are the head of their households is greater for women than for men. One in five women in female-headed households have some work disability; the comparable figure for male-headed households is one in eight. In the case in which the work disability is severe, femaleheaded households are twice as likely to have a head unable to work than are male-headed households. 
TABLE 2

Work Disability Status of Persons 18 - 64 Years of Age, By Sex and Selected Characteristics, U.S., 1976

\begin{tabular}{|c|c|c|c|c|c|c|c|c|}
\hline \multirow{3}{*}{ Characteristic } & \multicolumn{8}{|c|}{ With a Work Disability (Percent of total) } \\
\hline & \multicolumn{2}{|c|}{ Total } & \multicolumn{2}{|c|}{$\begin{array}{l}\text { Prevented } \\
\text { from Working }\end{array}$} & \multicolumn{2}{|c|}{$\begin{array}{l}\text { Unable to } \\
\text { Work Regularly }\end{array}$} & \multicolumn{2}{|c|}{$\begin{array}{l}\text { Able to } \\
\text { Work } \\
\text { Regularly }\end{array}$} \\
\hline & $\mathbf{M}$ & $\mathbf{F}$ & M & $\mathbf{F}$ & $\mathbf{M}$ & $\mathbf{F}$ & $\mathbf{M}$ & $\mathbf{F}$ \\
\hline Total & 13.3 & 13.3 & 5.1 & 6.4 & 1.4 & 2.1 & 6.7 & 4.9 \\
\hline Age & & & & & & & & \\
\hline $\begin{array}{l}18-24 \text { years } \\
25-29 \text { years } \\
30-34 \text { years } \\
35-44 \text { years } \\
45-54 \text { years } \\
55-64 \text { years }\end{array}$ & $\begin{array}{r}6.4 \\
7.6 \\
8.1 \\
10.2 \\
18.3 \\
29.4\end{array}$ & $\begin{array}{r}4.9 \\
6.2 \\
8.2 \\
11.5 \\
19.0 \\
29.5\end{array}$ & $\begin{array}{r}1.3 \\
2.0 \\
2.4 \\
3.2 \\
7.6 \\
14.7\end{array}$ & $\begin{array}{r}1.2 \\
1.9 \\
2.9 \\
4.5 \\
9.4 \\
17.9\end{array}$ & $\begin{array}{l}0.6 \\
0.7 \\
0.9 \\
1.2 \\
1.7 \\
3.6\end{array}$ & $\begin{array}{l}0.5 \\
1.0 \\
1.5 \\
2.0 \\
3.0 \\
4.3\end{array}$ & $\begin{array}{r}4.5 \\
4.9 \\
4.8 \\
5.8 \\
9.1 \\
11.2\end{array}$ & $\begin{array}{l}3.1 \\
3.3 \\
3.7 \\
5.1 \\
6.6 \\
7.2\end{array}$ \\
\hline $\begin{array}{l}\text { Marital Status } \\
\text { Married, spouse } \\
\text { Married, no spouse }\end{array}$ & $\begin{array}{l}13.0 \\
11.9\end{array}$ & $\begin{array}{l}11.8 \\
17.7\end{array}$ & $\begin{array}{l}4.7 \\
3.5\end{array}$ & $\begin{array}{l}5.3 \\
8.5\end{array}$ & $\begin{array}{l}1.2 \\
1.3\end{array}$ & $\begin{array}{l}2.0 \\
3.8\end{array}$ & $\begin{array}{l}7.1 \\
7.1\end{array}$ & $\begin{array}{l}4.5 \\
5.4\end{array}$ \\
\hline $\begin{array}{l}\text { Household Relationship } \\
\text { Head of household } \\
\text { Wife of head } \\
\text { Unrelated Indiv. }\end{array}$ & $\left|\begin{array}{c}13.2 \\
- \\
14.2\end{array}\right|$ & $\begin{array}{l}20.5 \\
11.8 \\
19.3\end{array}$ & $\begin{array}{c}4.8 \\
- \\
6.1\end{array}$ & $\begin{array}{r}9.9 \\
5.4 \\
10.3\end{array}$ & $\begin{array}{l}1.3 \\
- \\
1.9\end{array}$ & $\begin{array}{l}3.4 \\
2.0 \\
2.5\end{array}$ & $\begin{array}{c}7.1 \\
- \\
6.1\end{array}$ & $\begin{array}{l}7.3 \\
4.5 \\
6.5\end{array}$ \\
\hline
\end{tabular}

Source: U.S. Department of Health, Education, and Welfare, Office for Handicapped Individuals. D1gest of Data on Persons with Disabilities. (Washington, D.C.: Government Printing Office, 1979) Table 5, p. 17 .

Women are therefore more likely than men to be limited or prevented from working because of their disability, are likely to experience a higher degree of work disability at an earlier age than men, and are more likely to be without a spouse. Being married is particularly important to disabled persons because the presence of a spouse provides greater income and extra attention to personal care needs. Each of these factors support the urgent need of women to have available to them some form of public income support protection. But because of womens' more tenuous ties to the labor force, and the contingent relationship 
between disability programs and labor force participation, women are largely excluded from public disability benefits.

\section{Labor Force Participation of Women}

By mid-1977, forty million American women were in the labor force -about 41 percent of the country's entire labor force, and 49 percent of all women sixteen years of age and over. (By contrast, 77 percent of all men aged sixteen and over were in the labor force). Most women who work outside the home do so in clerical occupations ( 34.9 percent) and service sector jobs ( 17.9 percent). Of the 5.6 million women in professional and technical jobs in 1976, nearly 40 percent were elementary and secondary school teachers (U.S. Department of Labor, 1977).

While labor force participation by women has been increasing steadily in the last thirty years, women still constitute about threefourths of the population outside of the labor force. Most of these women do not want jobs because of their home and family responsibilities. Thus women who head families (especially divorced women) are more 1ikely to be in the labor force than wives living with their husbands.

Womens' participation in and rewards from work outside the home differ from mens' in several ways. First, women are more likely than men to work part-time or only for part of the year. The Bureau of Labor Statistics reports that of the 42.8 million who were employed in $1975,41.4$ percent worked all year ( 50 to 52 weeks), 25.7 percent worked part of the year ( 1 to 49 weeks), and 32.9 percent worked at part-time jobs. The comparable percentages for men are shown in Table 3 .

TABLE 3

Work Experience of Women and Men, 1975

\begin{tabular}{l|r|r}
\hline Work Experience & Women & Men \\
\hline Persons who worked & & \\
Number (in thousands) & 42,881 & 58,359 \\
Percent & 100 & 100 \\
Worked at full time Jobs & & \\
50 to 52 weeks & 41.2 & 63.9 \\
27 to 49 weeks & 12.2 & 13.3 \\
1 to 26 weeks & 13.5 & 10.3
\end{tabular}


TABLE 3 (cont.)

Work Experience of Women and Men, 1975

\begin{tabular}{l|r|l}
\hline Work Experience & Women & Men \\
\hline Worked at part-time job & & \\
50 to 52 weeks & 11.8 & 4.4 \\
27 to 49 weeks & 8.3 & 3.0 \\
1 to 26 weeks & 12.8 & 5.1 \\
\hline
\end{tabular}

Source: U.S. Department of Labor, Bureau of Labor Statistics. U.S. Working Women: A Databook. (Washington, D.C.: Government Printing Office, 1977), Table 14, p. 12.

In addition to working less than full time, women have been on their current fob a substantially shorter time, on average, than men. The largest differences are for persons age forty-five to sixty-four. These differences are highlighted in Table 4.

TABLE 4

Median Number of Years Worked at Current Job By Women and Men by Age, 1973

\begin{tabular}{l|c|c}
\hline \multirow{2}{*}{ Age Group } & \multicolumn{2}{|c}{ Median Number of Years } \\
\cline { 2 - 3 } & Women & Men \\
\hline Tota1, 16 years and over & 2.8 & 4.6 \\
16 to 19 & 0.6 & 0.6 \\
20 t0 24 & 1.2 & 1.2 \\
25 to 34 & 2.2 & 3.2 \\
35 to 44 & 3.6 & 6.7 \\
45 to 54 & 5.9 & 11.5 \\
55 to 64 & 8.8 & 14.5 \\
65 and over & 10.9 & 13.9 \\
\hline
\end{tabular}

Source: U.S. Department of Labor, Bureau of Labor Statistics. U.S. Working Women: A Databook. (Washington, D.C.: Government Printing Office, 1977), Table 56, p. 57.

Thus in 1973, the median number of years on the current job for a11 women employed was 2.8 years while for men it was 4.6 years. 
A final dimension upon which womens' relationship to work outside the home differs from that of mens' is compensation. The great majority of working women have not yet attained parity with working men in earned income. Women who worked at year-round, full-time jobs in 1977 earned only 59 cents for every dollar earned by men. This figure is actually down from the 1955 level of 64 cents for every dollar. A recent Department of Labor report notes: "Men's median week1y earnings exceeded women's by $\$ 116$, so that a woman had to work nearly nine days to gross the same earnings men grossed in five days." (U.S. Department of Labor, 1979). The situation is no better if educational level is taken into account. In both 1970 and 1974, the median income of women college graduates aged twenty-five and over who worked ful1-time was only 60 percent of the comparable male median income (U.S. Department of Commerce, 1976). Surveys of starting salaries of women and men graduating from college have for many years revealed differences in "offers" received by women and men job seekers. The majority of women continue to receive lower offers than men.

Thus, as most women workers continue to be concentrated in lower paying occupations that provide limfted opportunities for advancement, and as discrinination in hiring, promotion, and pay scales continue to be a major obstacle to equality for women in the workplace, womens' rewards from work outside the home are significantly less than mens'.

\section{Women and Public Programs}

All of the factors just reviewed as regards the labor force participation of women help explain why women receive fewer, and less generous benefits from public disability programs. Fewer women than men are in the labor force, and therefore fewer are eligible for coverage under disability insurance or workmans' compensation programs. Women engaged in full-tine homemaking activittes do not participate in the social security system at all, and therfore are not eligible for DI benefits should they become disabled. To be fully insured under the disability insurance program, workers must have contributed through their payroll taxes a proscrfbed number of quarters within a proscribed period of time. Both length of time worked during the year and tenure on the job, less for women than men, thus may exclude women from benefit entitlement under DI. And since DI benefit levels are indexed to earnings, even women workers covered under the program will receive substantially lower benefits than men if they become disabled. Program participation rates make clear the dtsadvantage disabled women face vis-a-vis our current public polictes on disability. 


\section{Participation of Women in Disability Programs}

In 1977 , of the 40.5 million women in the labor force, 32 million were insured by the Social Security Administration in the event of disability. A quarter of these were young women, under age twenty-five. As would be expected, coverage increases with age. About 74 percent of working women under age twenty-five were fully insured, 78 percent of those aged 25 to 54 , and 88 percent of those fifty-five and over (U.S. Department of Health, Education, and Welfare, 1978c). Thus in 1977, nearly 9 million American working women were without disability insurance protection under social security. While there are more men in the labor force than women, fewer men were uninsured (about 3 million).

Within the social security program, disability insurance benefits play a smaller part in providing income replacement for women than for men. Of the 1.88 million workers who were receiving DI benefits in 1976 , 1.15 were men and 730,000 were women. In the Social Security Administration 1972 Survey of Disabled and Nondisabled Adults only 9 percent of severely disabled women were found to be receiving benefits because of their disability. Fully one-third ( 33 percent) of the severely disabled men were receiving benefits. Additionally, twice as many severely disabled men as women received benefits for early retirement. The situation was reversed for dependents' benefits. Twice as many severely disabled women as men received benefits as dependents of disabled, retired, or deceased workers (Allan, 1976).

For the disabled worker, benefit levels vary by sex. The average benefit received by men in 1977 was $\$ 320.40$; the average benefit received by women was $\$ 228.50$. Those persons more recently gaining eligibility had, on average, higher benefit awards than earlier eligibles. A woman worker who became elibible for DI benefits between 1960 and 1964, for example, would be receiving an average monthly amount of $\$ 199.60$. One becoming elfgible between 1975 and 1977 would average $\$ 227.10$ (U.S. Department of Health and Human Services, Table 77, 1980). For those wives of disabled workers whose entitlement was based on children in their care, their average monthly benefit amount in 1977 was $\$ 76.80$ (U.S. Department of Health and Human Services, Table 67, 1980).

The average age of women workers who are receiving disability insurance benefits is about 52 years old. Fully 76 percent of women DI beneficiaries are between the ages of fifty and sixty-four. And it is these older disabled women workers who receive the lowest benefit levels from the program, and who are more likely to have fewer resources available to them. Many are widowed, divorced, or separated. Thus, 
while fewer disabled women than men benefit from the disability insurance program, even those who do remain seriously economically disadvantaged.

While underrepresented in the disability insurance program, women are overrepresented under supplemental security income. Public assistance is a more important source of income for women than for men, and becomes increasingly important with the severity of the limitation. Women now constitute about 60 percent of SSI beneficiaries reflecting their weaker work force attachment. For those women who have worked too little to gain eligibility under the disability insurance program, or who while eligible may only qualify for minimum DI benefits, public assistance in the form of supplemental security income offers the only means of support.

Public income maintenance programs such as workers' compensation and veterans disability programs are also less important for women than for men. (See Table 5). A study done in 1975 on the workers' compensation program of five states found that 82 percent of claimants were male and only 18 percent were female (Joe and Bogatay, 1980).

Rehabilitation services are available infrequently to disabled women. Due to the VR screening process and inadequate funding, not all individuals eligible for VR services receive them. Only onequarter of those awarded disability insurance or supplemental security income benefits in a given year are referred for rehabilitation services. Less than half of those referred are accepted into the program. Thus eight out of every nine beneficiaries do not receive VR services (Joe and Bogatay, 1980). And those who are referred are young -36.5 years old for DI clients, 29.8 years old for SSI clients (U.S. Department of Health, Education and Welfare, 1979b). The tyoical disabled woman, however, is more likely to an older recipient, and thus more likely to be screened out of the vocational rehabilitation process as having a lower potential for engaging in substantial gainful activity after rehabilitation. This bias towards providing services to individuals who can reenter the labor force effectively excludes women who may have been full-time homemakers, or who may have had tenuous labor market connections prior to the onset of their disability, or who may now be at an age where reentry into the labor force would be difficult because of age discrimination. 


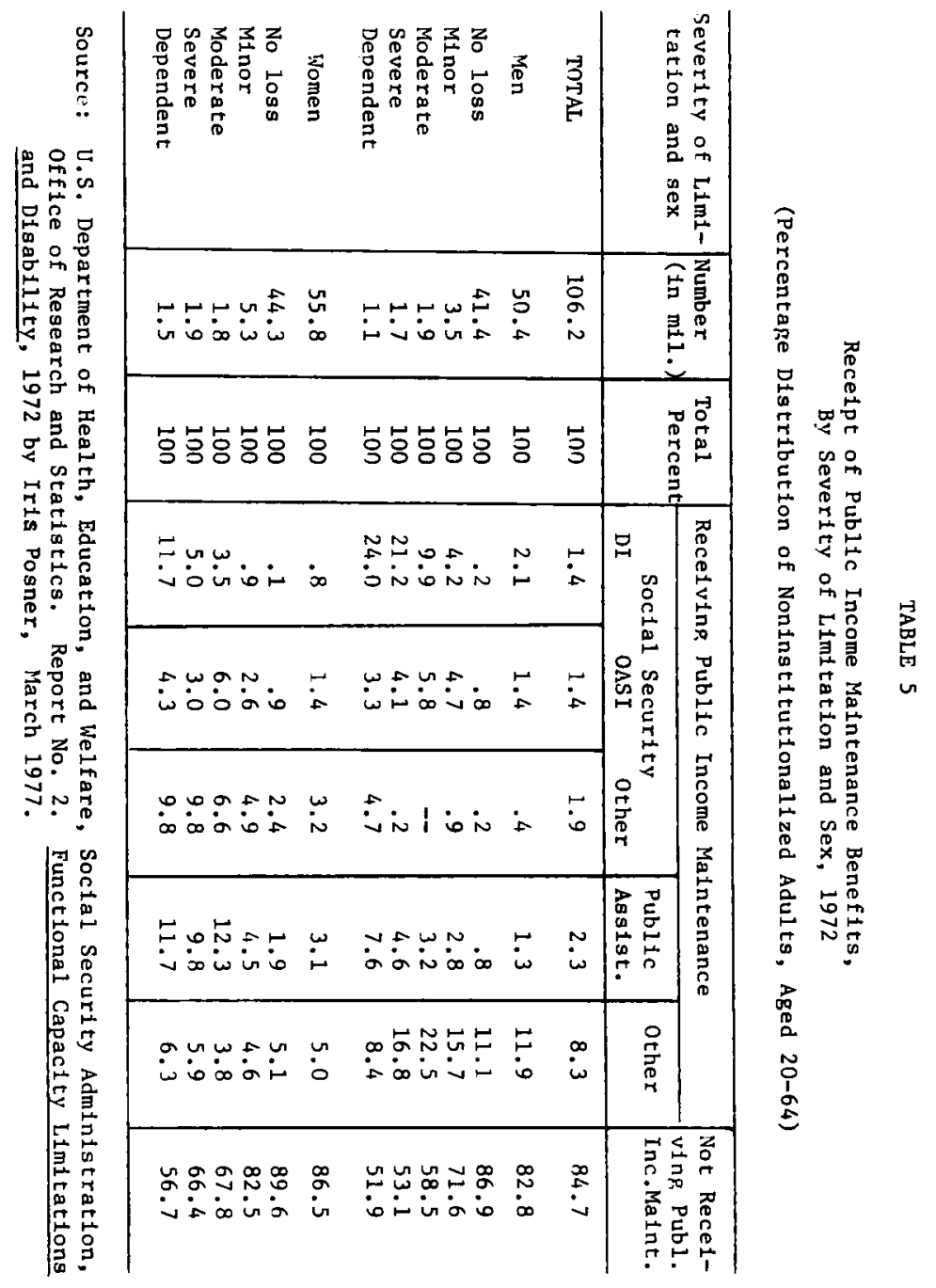




\section{Conclusions and Policy Implications}

After twenty years of development, disability policy in the United States is undergoing a serious reassessment. The role and function of disability insurance, public assistance, and rehabilitation services in the life of the disabled individual, both male and female, is being questioned. Application rates for the disability insurance program are rising, and so are the costs. Between 1970 and 1979 , the cost of DI cash benefits grew from $\$ 2.8$ to $\$ 13.6$ billion. Yet, the program experience for the period 1968 to 1978 reflects, in the words of one author, "...disqueting trends in terms of future cost potential, and apparent erosion of the rate in which disabled beneficiaries leave the benefit rolls for reasons other than death or the attainment of retirement age." (Joe and Bogatay, 1980, p. 132). Since 1960, yearly "recoveries" have remained constant at approximately 40,000 , although rolls have been steadily rising. In effect, than, over 90 percent of those who become DI beneficiaries never "recover." The resulting loss to the society of the economic contributions of these individuals is causing great concern. Countless proposals have recently been made to alter the various disability programs in such a way as to strengthen the incentives to reenter the labor force for those disabled who can, to increase the adequacy of public benefits for those who cannot, and to make more effective and efficient the available rehabilitation services (Sussman and Hagan, 1977; U.S. Advisory Council on Soclal Security, 1979; U.S. Senate Finance Committee, 1979).

Al1 of these proposals, if adopted, will strengthen United States policy on disability so as to more greatly benefit all disabled persons, men and women. But marginal improvements in program specifics will not solve what is a continuing problem for women -- the strong relationship between program benefit entitlement and labor force participation. As long as the mafor (and most generous) disability protection programs are premised upon a model of life-long, fulltime employment outside the home, with disability being explicitly defined in a work-related context, women will continue to be disadvantaged.

The policy implications of this "disadvantage" are different, of course, for women who are employed and those who are not. For the majority of the 41 percent of American adult women who are now in the labor force, disability insurance benefits under social security provide the primary income assurance program in the event of disability. Yet only 32 percent of recent successful applicants for the DI program were women, and of those applicants who were denied 
benefits, more than three-fourths had incomes under $\$ 4,000$. And for those women who qualify as beneficiaries, benefits remain low. Over 42 percent of female workers who are severely disabled are classified as service workers. These workers typically earn low wages (the median usual weekly earnings of full-time women service workers in 1976 was \$109), and about 31 percent have less than a high school education (U.S. Department of Labor, 1977). Thus, such workers would not only receive low benefits, but would be poor candidates for retraining.

The low benefits awarded women workers who become disabled result in a dramatic decline in their income. In 1970-71, 82.8 percent of recently disabled adult women experienced a drop in their yearly earnings of 50 percent or more (U.S. Department of Health, Education, and Welfare, 1979a). This decline has a differential effect on disabled women with spouses and those without. The estimated median family income of severely disabled married women in 1977 was $\$ 9,543$. For nonmarried women the figure was $\$ 2,225$ (Lando and Krute, 1976).

Thus, if they can qualify, employed women can rely upon disability insurance benefits in the event of disabiltty. But these benefits are likely to be very low and present a particular hardship for women who have no spouse present. Some older women who do not qualify for DI benefits on their own work record may be eligible for a disabled widow benefit under soctal security. But this category is very restrictive, serves few women, and provides a very low average monthly benefit.

For those 49 percent of women outside the labor force, fewer options are available in the event of disability. If married, they may qualify for the supplemental securtty income program. For these disabled women, their annual income guarantee would be no more than $\$ 2,856$, about 84 percent of the poverty line in this country.

The implications of the above data are clear. There is need for an urgent reassessment of the impact of current disability policy on the disabled woman. While labor force participation rates of women are on the rise, soctal circumstances of child rearing and homemaking will always keep large numbers of women from working outside the home. Increasing divorce and separation is also enlarging the number of female-headed households in this country. The presumption that the disabled woman will either be protected from a loss of income because of adequate disability insurance protection, or by the presence of a spouse is patently false. As long as those presumptions underlie major United States disability programs, women will remain unprotected from the economic threats associated with disabtlity. 


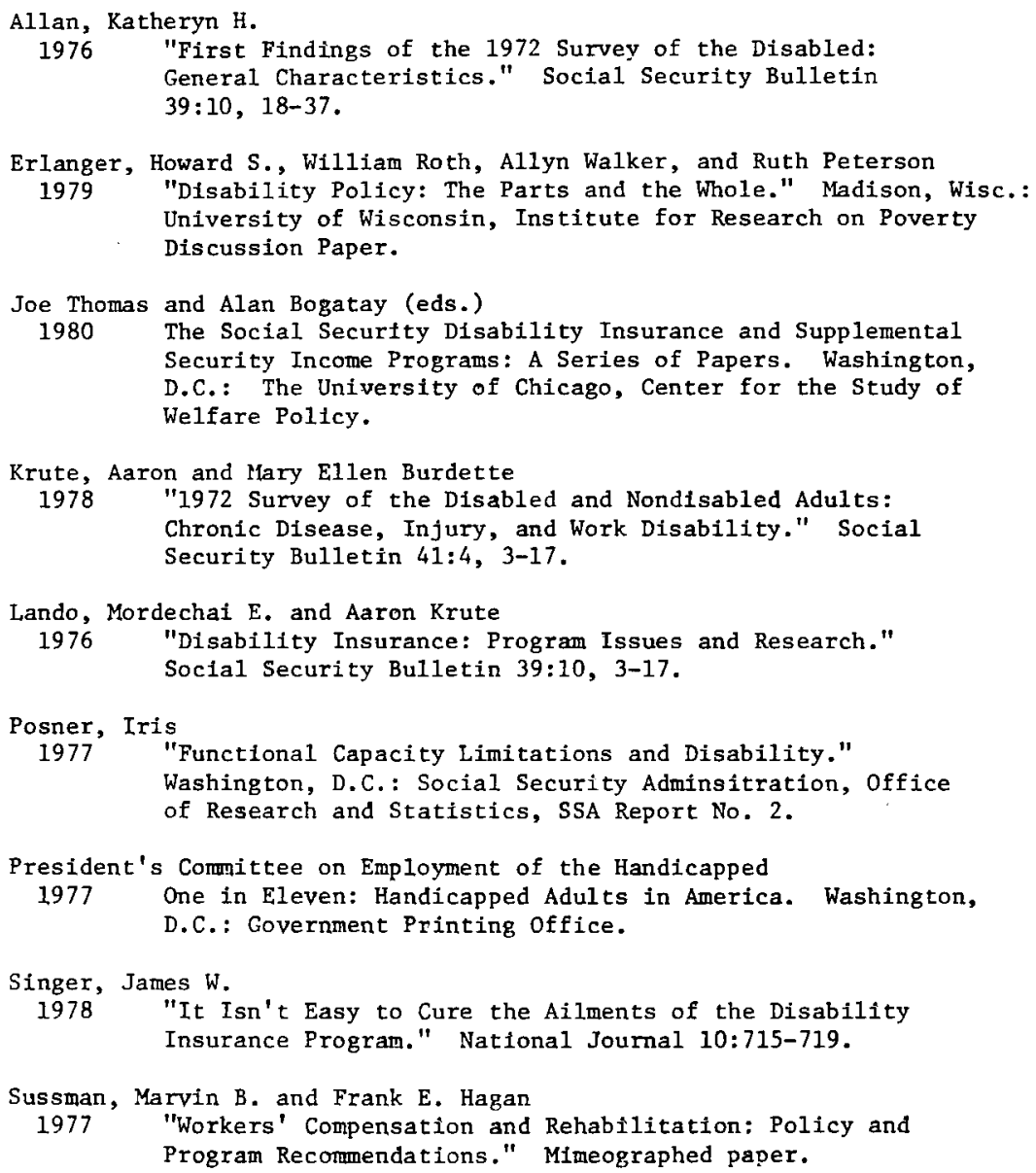


U.S. Advisory Council on Social Security

1979 Social Security Financing and Benefits. Washington, D.C.: U.S. Advisory Council on Social Security, Final Report.

U.S. Congress, Senate Finance Comittee

1979 "Issues Related to Social Security Act Disability Programs." 96th Cong., 1st sess.

U.S. Department of Commerce.

1976 Bureau of the Census. Current Population Reports. A Statistical Portralt of Women in the U.S. Series P-23, No. 58.

U.S. Department of Health, Education, and Welfare

1974 Social Security Administration. Social Security Handbook. Washington, D.C.: Govermment Printing Office.

1978a Office for Handicapped Individuals. Federal Assistance for Programs Serving the Handicapped. Washington, D.c.: Government Printing office.

1978b Rehabilitation Services Administration. State Vocational Rehabilitation Agency Program Data: Fiscal Year 1977. Washington D.C.: Government Printing Office.

1978c Social Security Administration. Social Security Bulletin: Annual Statistical Supplement, 1976. Washington, D.C.: Government Printing Office.

1979a Office for Handicapped Individuals. Digest of Data on Persons with Disabilities. Washington, D.C.: Government Printing office.

1979b Rehabilitation Services Administration. RSA Annual Report: FY 1978. Washington, D.C.: Government Printing Office.

1980 Social Security Administration. Social Security Bulletin: Annual Statistical Supplement, 1977-1979. Washington, D.C.: Government Printing Office.

U.S. Department of Labor

1977 Bureau of Labor Statistics. U,S. Working Women: A Databook. Washington, D.C.: Government Printing office. 
U.S. Department of Labor

1979 Women's Bureau. The Earnings Gap Between Women and Men. Washington, D.C.: Government Printing office.

U.S. Office of Management and Budget

1979 Speclal Analysis, Budget of the United States Government: Fiscal Year 1979. Washington, D.C.: Government Printing office. 


\section{INTRUDECIION}

Fis story is meant to be read primarily by or to children of elementary schocl age as it is written in lnngusge thiat tiey can identify with and understind. It is also intended as reading for social workers and educators for the purpose of enkancing their understanding of trie enotional dilemmas eyperienced by abused children. Ispecially stressed are the feelings of amoivalence, betrayal, anger, loss, concern, guilt, desertion, saddness and loyalty to one's parents/caretakers, no matter how vad tie situation may seer or how urgent the need for placement.

This paper poses for thought the author's feeling that oppression breeds anger which results in unnecessary pressure being brought to bear upon the oppressed, whether tis is pressure to conform or pressure to rebel. This oppression, when not dealt with, or when dealt with unsuccessfuliy or inappropriately, can lead to the ongoing stress that is evident in situations of abuse.

A secondary purpose of this paper is to point out some of the s-ortcomings of foster placement - both in the area of pre-placement preparation as well as the child's need to maintain some type of contact with his/her home situation wille in placement. Because it is very difficult for any child to experience and understand all of the emotions that surface prior to, during and after placement, this story is meant to convey the message that only in the most necessary of circumstances should a child be removed from home. 